\title{
Batas aman konsumsi ikan tongkol pasar dupa Pekanbaru ditinjau dari kandungan logam $\mathrm{Pb}$ dan $\mathrm{Cu}$
}

\author{
Fitria Roza ${ }^{1}$, Efriyeldi $^{2}$, Rasoel Hamidy ${ }^{2}$ \\ ${ }^{1}$ Mahasiswa Pascasarjana Ilmu Lingkungan Program Pascasarjana Universitas Riau. \\ ${ }^{2}$ Dosen Pascasarjana Ilmu Lingkungan Program Pascasarjana Universitas Riau.
}

\begin{abstract}
Based on toxicology viewpoint, heavy metals can be divided into 2 types. The first type is essential heavy metals, which is in a certain amount is needed by living organisms, but in excessive amounts can cause toxic effects, such as $\mathrm{Zn}, \mathrm{Cu}, \mathrm{Fe}$, Co and $\mathrm{Mn}$. The second type is non-essential, which is in the organism body is still not known the benefit of this heavy metals even it can be become a toxic in our body, such as $\mathrm{Hg}, \mathrm{Cd}, \mathrm{Pb}$ and $\mathrm{Cr}$. The purpose of this research is to 1) analyzing the concentration of heavy metals $\mathrm{Pb}$ and $\mathrm{Cu}$ on the tuna fish which is sold in the Dupa Market Pekanbaru, and 2)analyzing the content of heavy metals $\mathrm{Pb}$ and $\mathrm{Cu}$ on Tuna, whether it has exceeded or not the threshold of SNI 2009. The study has been conducted in June to July 2015 in Dupa Market Pekanbaru City. The method used in this study is a survey method. The result showed that heavy metals $\mathrm{Pb}$ and $\mathrm{Cu}$ have the highest metal content are derived from Sibolga waters. The heavy metals content of tuna in Dupa Market of Pekanbaru were $\mathrm{Pb}$ of $1-3.98 \mathrm{ug} / \mathrm{g}$ and $\mathrm{Cu}$ of $0.22-0.93 \mathrm{ug} / \mathrm{g}$. The Safety limit consumption of tuna in Dupa Market Pekanbaru are $\mathrm{Pb}$ of $3.89 \mathrm{~kg} /$ week and $\mathrm{Cu}$ of $2456.76 \mathrm{~kg} /$ week. Based on this results showed the status for heavy metals of $\mathrm{Pb}$ and $\mathrm{Cu}$ on Tuna fish that sold at Dupa Market Pekanbaru is still safe and consumable.
\end{abstract}

Keywords: Food; Tuna; Heavy Metals

Berdasarkan sudut pandang toksikologi, logam berat ini dapat dibagi dalam dua jenis. Jenis pertama adalah logam berat esensial, di mana keberadaannya dalam jumlah tertentu sangat dibutuhkan oleh organisme hidup, namun dalam jumlah yang berlebihan dapat menimbulkan efek racun, contohnya adalah $\mathrm{Zn}, \mathrm{Cu}, \mathrm{Fe}, \mathrm{Co}$, dan $\mathrm{Mn}$. Jenis kedua adalah logam berat non-esensial, di mana keberadaannya dalam tubuh masih belum diketahui manfaatnya atau bahkan dapat bersifat racun, seperti $\mathrm{Hg}, \mathrm{Cd}, \mathrm{Pb}$, dan Cr.

Ikan sebagai pemangsa puncak (top predator) di perairan akan mendapatkan (intake) pencemar secara aktif melaui rantai makanan, dan atau terserap secara pasif melalui lingkungan melalui proses pengaturan tekanan osmose cairan tubuh (osmoregulasi). Ikan yang hidup pada kolom air yang tercemar logam berat akan menyerap secara pasif ion positif (kation) dari lingkungannya melalui berbagai tahapan sistem organ. Perjalanan pencemar tersebut melalui difusi ke kulit (uptake), melalui peredaran ginjal, melalui saluran pencernaan ke daging, hati dan empedu. Secara fisiologis ikan memiliki sistem eliminasi pencemar dari dalam tubuhnya. Namun pencemar yang masuk aktif melalui rantai makanan (feeding) akan mengalami biotransformasi dan terakumulasi dalam sistem daging sesuai dengan pertumbuhan biomassa ikan yang bersifat tidak dapat berbalik (irreversible) dan bila dikonsumsi oleh manusia maka akan tertimbun biomassa manusia (Parningotan, 2010).

Beberapa tahun yang lalu perairan Teluk Jakarta dan Teluk Buyat di Indonesia sempat diisukan telah terjadi pencemaran logam berat (Amin, 2013). Logam berat merupakan klasifikasi untuk logam yang menimbulkan toksisitas (Duffus, 2002). Keracunan logam berat dapat merusak sistem syaraf pusat, mengganggu komposisi darah, paru-paru, ginjal, hati dan organ-organ vital lainnya. Pemaparan dalam jangka panjang dapat menurunkan proses degeneratif fisik, otot, dan syaraf. Alergi juga dapat timbul dan kontak berulang dengan beberapa logam, atau komponennya dapat menyebabkan karsinogenitas. Sumber utama dari logam berat termasuk pertambangan dan industry seperti pengecoran, pengilangan minyak, petrokimia dan industri kimia, pipa besi yang terbuang, gas pembuangan kendaraan bermotor dan juga pertambangan batu bara (Dinis, 2011). Menurut Scott (1981) unsur Timbal dan Kadmium biasa digunakan dalam industri dan menimbulkan toksisitas pada hewan dan pada proses aerobik dan anaerobik.

Menurut ketentuan WHO dalam Sudarmaji (2006) kadar Pb dalam darah manusia yang tidak terpapar oleh $\mathrm{Pb}$ adalah sekitar $10-25 \pi \mathrm{g} / 100 \mathrm{ml}$. Paparan bahan tercemar $\mathrm{Pb}$ dapat menyebabkan gangguan pada organ sebagai berikut: gangguan neurologi, gangguan terhadap fungsi ginjal, ganguan terhadap sistem reproduksi. Logam berat $\mathrm{Pb}$ mempunyai efek racun terhadap gamet dan dapat menyebabkan cacat kromosom.

Logam tembaga $(\mathrm{Cu})$ merupakan mikro elemen esensial untuk semua tanaman dan hewan, termasuk manusia. Logam $\mathrm{Cu}$ diperlukan oleh berbagai sistem enzim di dalam tubuh manusia. Oleh 
karena itu, $\mathrm{Cu}$ harus selalu ada dalam makanan. Untuk itu yang perlu diperhatikan adalah menjaga agar kadar $\mathrm{Cu}$ di dalam tubuh tidak kekurangan dan juga tidak berlebihan (Lubis, 2001). Pencemaran tembaga $(\mathrm{Cu})$ biasanya berasal dari peralatan listrik, peleburan logam, katalisator, algasida, dan pengawet kayu (Arisandi, 2004).

Ikan laut yang dijual di Pasar Dupa Pekanbaru juga tidak lepas dari kandungan logam berat. Ikan tongkol merupakan salah satu ikan laut yang banyak dijual di Pasar Dupa Pekanbaru. Kota Pekanbaru berada sangat jauh dari laut, sehingga pasokan ikan segar pada sejumlah pasar di Kota Pekanbaru berasal dari daerah-daerah tetangga bahkan provinsi tetangga seperti dari Tanjung Balai Asahan Sumatera Utara, Sibolga Sumatera Utara, Padang Sumatera Barat dan Pasaman/Air Bangis Sumatera Barat.

\section{METODE PENELITIAN}

Penelitian dilaksanakan pada bulan Juni sampai dengan Juli 2015. Lokasi pengambilan sampel ikan tongkol yang diteliti adalah Pasar Dupa Kota Pekanbaru. Daging ikan tongkol dianalisa menggunakan Atomic Absorption Spectrophotometer (AAS) merek PERKIN ELMER 3110. Bahan yang digunakan dalam penelitian ini adalah ikan tongkol Pasar Dupa Pekanbaru. Bahan kimia yang digunakan adalah larutan standar $\mathrm{Pb}$ dan $\mathrm{Cu}$.

Metode yang digunakan dalam penelitian ini adalah metode survei, di mana pasar Dupa Kota Pekanbaru dijadikan lokasi pengambilan sampel ikan tongkol dan konsumen ikan tongkol.

\section{Analisis konsentrasi logam $\mathrm{Pb}$ dan $\mathrm{Cu}$}

Kandungan logam berat $\mathrm{Pb}$ dan $\mathrm{Cu}$ pada daging ikan tongkol dianalisis menggunakan Atomic Absorption Spectrophotometer (AAS) merek PERKIN ELMER 3110. Sebelum dilakukan pengukuran dengan AAS, daging ikan didestruksi dikelompokkan berdasarkan sumber asal ikan tongkol. Sampel ikan tongkol dicuci dan kemudian dikeringkan dalam oven pada suhu $80^{\circ} \mathrm{C}$ selama 24 jam atau sampai mencapai berat konstan, lalu didinginkan dan ditimbang. Kemudian diambil masing-masing sampel berdasarkan sumber asal ikan tongkol untuk ulangan sebanyak 1 gram didestruksi di dalam $10 \mathrm{ml} \mathrm{HNO}$ s pekat. Kemudian dipanaskan dengan pemanas (hot plate) pada suhu rendah $\left(40^{\circ} \mathrm{C}\right)$ selama 1 jam dan dilanjutkan pada suhu tinggi $\left(140^{\circ} \mathrm{C}\right.$ ) selama \pm 3 jam (Yap et al, 2003) dan setelah itu sampel didinginkan pada suhu ruangan.

Larutan sampel yang telah didinginkan kemudian ditambah air suling sehingga volumenya menjadi $50 \mathrm{ml}$, kemudian disaring dengan kertas saring $0,45 \mu \mathrm{m}$ menghindari penyumbatan pipa kapiler saat analisis pada AAS ke dalam botol PE $60 \mathrm{ml}$ dan sampel siap dianalisis. Selanjutnya sampel siap diukur kandungan logam beratnya menggunakan AAS dengan menggunakan lampu katoda sesuai dengan jenis logam berat yang diukur. Sampel daging ikan tongkol juga dilakukan pengukuran berat kering atau kadar air yang dipakai untuk pengukuran Provisional Tolerable Weekly Intake (PTWI) dalam berat basah.

Selain melakukan destruksi, terhadap sampel juga dilakukan pembuatan larutan blanko. Ini dimaksudkan untuk mendapatkan hasil penganalisa yang benar-benar berasal dari sampel. Hasil penganalisa sampel dikurangi dengan hasil pengukuran blanko.

Pembuatan larutan standar dilakukan untuk mendapatkan gambaran hubungan antara konsentrasi dengan nilai absorbansinya. Larutan standar dibuat dari larutan konsentrasinya, masing-masing $0,5 \mathrm{ppm}, 1$ ppm, 2 ppm dan 3 ppm, untuk setiap jenis logam yang diukur.

\section{Perhitungan kandungan logam berat $\mathrm{Pb}$ dan $\mathrm{Cu}$}

Perhitungan kandungan logam berat pada sampel dilakukan menurut rumus yang dipakai oleh Razak (1987), sebagai berikut:

$$
\mathrm{K}=\frac{\mathrm{D} \times \mathrm{B}}{\mathrm{A}}
$$

Keterangan :

$\mathrm{K}=$ Konsentrasi yang sebenarnya dari sampel $(\mu \mathrm{g} / \mathrm{gr})$

$\mathrm{D}=\quad$ Kandungan yang dihitung berdasarkan nilai absorbansi $(\mu \mathrm{g} / \mathrm{ml})$

$\mathrm{B}=$ Volume sampel $(\mathrm{ml})$

$\mathrm{A} \quad=\quad$ Berat sampel $(\mathrm{g})$

Kandungan residu logam berat $\mathrm{Pb}$ dan $\mathrm{Cu}$ dianalisis menggunakan AAS PERKIN ELMER 3110. Lampu katoda pada alat ini menghasilkan energi. Lampu ini dilapisi logam berat dari unsur-unsur yang akan dianalisis. Pembacaan AAS adalah pembacaan absorbansinya. Analisis konsentrasi logam berat $\mathrm{Pb}$ dan $\mathrm{Cu}$ menggunakan campuran udara asetilen sebagai sumber energi. 


\section{Tingkat keaman konsumsi}

Untuk mengetahui tingkat keamanan dalam mengkonsumsi ikan tongkol Pasar Dupa Pekanbaru, maka dilakukan penghitungan PTWI (Provision Tolerable Weekly Intake). FAO/WHO Expert Commite of Additves dalam Turkmen (2008) menetapkan PTWI untuk mengetahui keamanan dalam mengkonsumsi makanan laut termasuk ikan tongkol yang mengandung logam berat supaya tidak terakumulasi di dalam tubuh sehingga membahayakan kesehatan. PTWI untuk logam $\mathrm{Pb}$ yang ditetapkan adalah $0,025 \mathrm{mg} / \mathrm{kg}$ berat badan per minggu yang setara dengan $1.750 \mu \mathrm{g} / \mathrm{kg}$ logam $\mathrm{Pb}$ per minggu untuk $70 \mathrm{~kg}$ berat tubuh orang dewasa. Logam Cu sebesar $3,5 \mathrm{mg} / \mathrm{kg}$ berat badan per minggu yang setara dengan $245.000 \mu \mathrm{g} / \mathrm{kg}$ logam $\mathrm{Cu}$ per minggu untuk $70 \mathrm{~kg}$ berat tubuh orang dewasa. Menurut FAO/WHO tahun 2008 persamaannya sebagai berikut:

$$
\text { PTWI }=\text { Baku mutu logam } \times \text { berat badan } \times 1000
$$

Data yang diperoleh disajikan dalam bentuk tabel dan histogram, kemudian dianalisis secara statistik dan dibahas secara deskriptif. Untuk menganalisis perbedaan kandungan logam berat dan sumber asal ikan tongkol dilakukan dengan Anova dengan menggunakan program SPSS dan dilanjut dengan uji lanjut LSD.

\section{HASIL DAN PEMBAHASAN}

\section{Kondisi Umum Pasar Dupa Pekanbaru}

Pasar Dupa Pekanbaru berada di Jalan Gelatik di depan Rumah Sakit Awal Bross J1. Jenderal Sudirman Pekanbaru yang berkantor pusat di JI. Bahana Nomor 04 Lantai II dan kantor cabangnya berada di Jl. Merpati Pasar Pagi Tangkerang Pekanbaru. Pasar Dupa merupakan pasar tradisional milik keluarga Bapak H. Amizar Hamid yang dikelola secara pribadi. Luasnya \pm 1 Ha dengan jumlah kios 322 unit, di mana yang berfungsi 210 unit sedangkan 112 unit masih kosong. Selain kios terdapat juga 327 unit meja, 15 unit kedai, dan 10 unit ruko. Pada los pedagang ikan laut terdapat 38 orang pedagang dan khusus penjual ikan tongkol terdapat 17 orang pedagang.

Sarana dan prasarana pendukung Pasar Dupa Pekanbaru terdiri dari mushalla sebanyak 3 unit, masjid 1 unit, WC umum 4 unit, gedung kantor pengelola 1 unit, Bank BRI, Koperasi Pasar Tangkerang (Kopasta), dan lahan parkir. Untuk keamanan disediakan satpam, aparat kepolisian, dan personel TNI Angkatan Darat. Jam operasional pasar mulai dari jam 04.00 WIB sampai dengan 14.00 WIB. Para pemasok ikan dari berbagai daerah mulai berdatangan pada pukul 04.00 WIB. Para pemasok tersebut antara lain Bapak Khairul, Adi, dan Udin yang merupakan pemasok ikan laut. Ikan laut yang datang umumnya menggunakan kemasan Styrofoam yang dilapisi es.

\section{Kandungan Logam Pb dan $\mathrm{Cu}$ dan Batas Aman Konsumsi Ikan Tongkol Pasar Dupa Pekanbaru}

\section{Pengelompokan ikan tongkol Pasar Dupa Pekanbaru berdasarkan asal dan ukuran}

Ikan tongkol yang dijual di Pasar Dupa Pekanbaru berasal dari 4 daerah asal yaitu Padang (Sumatera Barat), Air Bangis (Sumatera Barat), Sibolga (Sumatera Utara), dan Tanjung Balai Asahan (Sumatera Utara).

\section{Jenis Ikan Tongkol Pasar Dupa Pekanbaru Berdasarkan Daerah Asal}

Ikan tongkol yang dijual di Pasar Dupa Pekanbaru yang berasal dari berbagai daerah terdiri dari dua jenis. Hasil identifikasi terhadap ikan yang dijual di Pasar Dupa Pekanbaru pada Tabel 1.

Tabel 1. Pengelompokan Jenis Ikan Tongkol Berdasarkan Daerah Asal dan Jenis Ikan Tongkol

\begin{tabular}{ccc}
\hline No & Daerah Asal & Jenis Ikan Tongkol \\
\hline 1. & Tanjung Balai Asahan & Euthynnus affinis \\
2. & Sibolga & Euthynnus affinis \\
3. & Padang & Euthynnus affinis \\
4. & Air Bangis & Euthynnus pelamis \\
\hline
\end{tabular}

Pada Tabel 1 dapat dilihat bahwa ikan tongkol yang dijual di Pasar Dupa Pekanbaru umumnya jenis ikan tongkol Euthynnus affinis. Ikan tongkol yang berasal dari daerah Tanjung Balai Asahan, Sibolga, dan Padang jenis ikan tongkolnya adalah Euthynnus affinis dan daerah asal ikan tongkol Air Bangis jenis ikan tongkolnya adalah Euthynnus pelamis

\section{Kandungan logam $\mathrm{Pb}$ dan $\mathrm{Cu}$ ikan tongkol Pasar Dupa Pekanbaru}

Kandungan rata-rata logam $\mathrm{Pb}$ dan $\mathrm{Cu}$ ikan tongkol di Pasar Dupa Pekanbaru dari daerah asal yang berbeda dapat dilihat pada Tabel 2 . 
Tabel 2. Kandungan Logam $\mathrm{Pb}$ dan $\mathrm{Cu}$ dan Hasil Uji LSD Ikan Tongkol yang dijual di Pasar Dupa

\begin{tabular}{|c|c|c|}
\hline \multirow[t]{2}{*}{ Daerah Asal } & \multicolumn{2}{|c|}{ Kandungan Logam Dalam Berat Kering $(\mu \mathrm{g} / \mathrm{g})$} \\
\hline & $\mathrm{Pb}$ & $\mathrm{Cu}$ \\
\hline Tanjung Balai Asahan & $1,00^{\mathrm{a}} \pm 0,08$ & $0,22^{\mathrm{a}} \pm 0,02$ \\
\hline Padang & $1,04^{\mathrm{a}} \pm 0,09$ & $0,22^{\mathrm{a}} \pm 0,03$ \\
\hline Sibolga & $3,98^{\mathrm{b}} \pm 0,15$ & $0,93^{b} \pm 0,02$ \\
\hline Air Bangis & $1,16^{\mathrm{a}} \pm 0,06$ & $0,22^{a} \pm 0,02$ \\
\hline Baku Mutu & 2 & 1 \\
\hline
\end{tabular}

$\mathrm{Pb}$ tertinggi berasal dari daerah Sibolga sebesar 3,98 $\mu \mathrm{g} / \mathrm{g}$ dan terendah dari daerah Tanjung Balai Asahan sebesar 1,00 $\mu \mathrm{g} / \mathrm{g}$. Apabila dibandingkan dengan baku mutu $\mathrm{Pb}$ sebesar $2 \mu \mathrm{g} / \mathrm{g} \mathrm{Pb}$ dari daerah Sibolga sudah melebihi baku mutu. Hasil penelitian pembanding kandungan logam $\mathrm{Pb}$ pada ikan tongkol yang dijual di Pasar Rejomulyo Kota Semarang kisaran 0,42 - 0,61 $\mu \mathrm{g} / \mathrm{g}$ (Hananingtyas, 2011). Ikan tongkol yang dijual di Pasar Rejomulyo Semarang masih dibawah baku mutu.

$\mathrm{Pb}$ merupakan salah satu logam non esensial yang dapat menimbulkan keracunan apabila terakumulasi cukup besar di dalam tubuh makhluk hidup (Darmanto dalam Emirsida, 2014). Secara alami $\mathrm{Pb}$ masuk ke perairan melalui pengkristalan di udara dengan bantuan air hujan dan pelapukan bantuan mineral akibat hempasan gelombang (Darmanto, 2001). Menurut ketentuan WHO dalam Sudarmaji (2006) kadar $\mathrm{Pb}$ dalam darah manusia yang tidak terpapar oleh $\mathrm{Pb}$ adalah sekitar $10-25 \mathrm{\pi g} / 100 \mathrm{ml}$. Paparan bahan tercemar $\mathrm{Pb}$ dapat menyebabkan gangguan pada organ sebagai berikut: gangguan neurologi, gangguan terhadap fungsi ginjal, ganguan terhadap sistem reproduksi. Logam berat $\mathrm{Pb}$ mempunyai efek racun terhadap gamet dan dapat menyebabkan cacat kromosom.

$\mathrm{Cu}$ tertinggi berasal dari Sibolga sebesar $0,93 \mu \mathrm{g} / \mathrm{g}$ dan terendah berasal dari Tanjung Balai Asahan sebesar $0,22 \mu \mathrm{g} / \mathrm{g}$ dilihat dari baku mutu kandungan logam berat $\mathrm{Cu} 1 \mu \mathrm{g} / \mathrm{g}$ masih dibawah baku mutu semuanya. Peneliti sebelumnya pada ikan nila di Keramba Danau Rawa Pening Semarang mengandung logam $\mathrm{Cu}$ 0,73 - 0,86 $\mu \mathrm{g} / \mathrm{g}$ (Hidayah, 2013). Kandungan $\mathrm{Cu}$ ikan nila di Keramba Danau Rawa Pening Semarang masih dibawah baku mutu.

$\mathrm{Cu}$ merupakan unsur yang berbentuk kristal dengan warna kemerahan. Tembaga di perairan berasal dari proses erosi batuan mineral, penambangan, galangan kapal dan buangan domestik dengan bahan dasar logam campuran dengan tembaga. Tembaga masuk ke dalam tatanan lingkungan berada dalam bentuk debu-debu dan partikulat tembaga yang ada dalam lapisan udara dan dibawa turun oleh air hujan (Amin, 2013). Tidak seperti logam-logam $\mathrm{Hg}, \mathrm{Pb}$, dan $\mathrm{Cd}$, logam tembaga $(\mathrm{Cu})$ merupakan mikroelemen esensial untuk semua tanaman dan hewan, termasuk manusia. Logam $\mathrm{Cu}$ diperlukan oleh berbagai sistem enzim di dalam tubuh manusia. Oleh karena itu, $\mathrm{Cu}$ harus selalu ada dalam makanan. Untuk itu yang perlu diperhatikan adalah menjaga agar kadar $\mathrm{Cu}$ di dalam tubuh tidak kekurangan dan juga tidak berlebihan (Lubis, 2001). Pencemaran tembaga $(\mathrm{Cu})$ biasanya berasal dari peralatan listrik, peleburan logam, katalisator, algasida, dan pengawet kayu (Arisandi, 2004)

Berdasarkan uji statistik yang dilakukan terlihat ada nya perbedaan jumlah kadar logam berat pada ikan tongkol berdasarkan daerah asalnya. Ikan tongkol yang berasal dari daerah Sibolga memiliki kandungan logam berat $\mathrm{Pb}$ dan $\mathrm{Cu}$ tertinggi dibandingkan daerah lainnya. Hasil analisis kandungan logam $\mathrm{Pb}$ dan $\mathrm{Cu}$ pada ikan tongkol yang dijual di Pasar Dupa Pekanbaru berdasarkan daerah asal, diketahui bahwa daerah asal mempunyai pengaruh terhadap kandungan logam berat. Hal ini kemungkinan disebabkan oleh kondisi perairan masing-masing daerah yang berbeda tingkat pencemarannya. Banyaknya kawasan industri pada daerah perairan dapat menyebabkan semakin tingginya tingkat pencemaran logam berat. Menurut Agarwal (2009), logam berat dalam jumlah besar, terpapar ke lingkungan melalui limbah industri, sampah organik, pembakaran sampah, generator listrik dan emisi transportasi.

Hasil uji Anova pada masing-masing logam didapat nilai $\mathrm{F}$ hitung $>\mathrm{F}$ Tabel. Hal tersebut menggambarkan bahwa terdapat perbedaan yang nyata kandungan logam $\mathrm{Pb}$ dan $\mathrm{Cu}$ dari daerah asal. Untuk mengetahui daerah mana yang berbeda tersebut maka dilakukan uji lanjut. Uji lanjut tersebut menggunakan uji LSD disajikan pada Tabel 2. Dari hasil uji lanjut LSD terlihat bahwa daerah asal memberikan pengaruh terhadap kandungan logam berat ikan tongkol. Kandungan logam berat yang berasal dari daerah Sibolga berbeda nyata dengan ikan tongkol yang berasal dari daerah lain.

Berita dari Medan Bisnis tanggal 24 Oktober 2011, adanya aktivitas bongkar muat batu bara yang dipasok ke PLTU Labuhan Angin. Aktivitas bongkar muat ini dikhawatirkan berdampak pencemaran laut Sibolga, karena debu dan serpihan batubara saat bongkar muat berlangsung ada yang terbuang ke laut. Berita Medan Bisnis tanggal 23 Juli 2013, pinggiran pantai Kabupaten Tapanuli Tengah (Tapteng) dan 
Kota Sibolga mulai tercemar. Semakin hari kondisi bibir pantai semakin memprihatinkan dan semakin kotor. Adanya sampah-sampah hasil limbah rumah tangga tampak mengapung dipermukaan laut. Disamping tumpukan sampah menumpuk dimana-mana, khusus di daerah industri perikanan seperti di Pondok Batu Tapteng dan Jalan Mojopahit Sibolga, air laut tampak menghitam, disebabkan tumpahan minyak dari kapal-kapal penangkap ikan yang bersandar dikawasan itu.

Berita dari Tempo tanggal 18 Januari 2014, Kapal Caraka Jaya Niaga III mengalami kebocoran dan mengalirkan bahan kimia di Pelabuhan Sambas Sibolga Sumatera Utara. Kapal milik Meratus Lines tersebut mengangkut bahan kimia milik PT Agincourt Resources, yang bergerak di bidang pertambangan emas di Tapanuli Selatan. Menurut heryanto (2016), wilayah laut Sibolga di Desa Nauli Kabupaten Tapanuli Tengah terdapat tempat pembuangan akhir (ash dispol area) sisa pembakaran batubara dalam bentuk padatan (ash batubara).

\section{Batas Aman Konsumsi Ikan Tongkol Pasar Dupa Pekanbaru}

Menurut Standar Nasional Indonesia (2009), penentuan batas aman konsumsi atau kelayakan konsumsi dilakukan dengan mengacu pada nilai PTWI. Nilai PTWI untuk logam Pb adalah $0,025 \mathrm{mg} / \mathrm{Kg}$ berat badan per minggu yang setara dengan $1.750 \mu \mathrm{g} / \mathrm{Kg}$ logam $\mathrm{Pb}$ per minggu untuk $70 \mathrm{Kg}$ berat tubuh orang dewasa. Logam Cu sebesar 3,5 mg/Kg berat badan per minggu yang setara dengan $245.000 \mu \mathrm{g} / \mathrm{Kg}$ logam $\mathrm{Cu}$ per minggu untuk $70 \mathrm{Kg}$ berat tubuh orang dewasa.

Berdasarkan hasil penelitian yang sudah dilakukan, untuk mengkonversikan berat kering menjadi berat basah digunakan perbandingan 1:4, sehingga diperoleh hasil perhitungan batas aman konsumsi ikan tongkol yang dijual di Pasar Dupa Pekanbaru seperti dapat dilihat pada Tabel 3.

Tabel 3. Batas Aman Konsumsi Ikan Tongkol yang dijual di Pasar Dupa Pekanbaru

\begin{tabular}{cccc}
\hline \multirow{2}{*}{ Logam } & $\begin{array}{c}\text { Kandugan Logam Dalam } \\
\text { Berat Basah }(\mu \mathrm{g} / \mathrm{g})\end{array}$ & $\begin{array}{c}\text { Nilai PTWI Masing- } \\
\text { masing Logam }(\mu \mathrm{g} / \mathrm{Kg})\end{array}$ & $\begin{array}{c}\text { Batas Aman Konsumsi Ikan } \\
\text { Tongkol }(\mathrm{Kg} / \text { minggu })\end{array}$ \\
\hline $\mathrm{Pb}$ & 0,45 & 1.750 & 3,89 \\
$\mathrm{Cu}$ & 0,10 & 245.000 & 2456,76 \\
\hline
\end{tabular}

Pada Tabel 3 terlihat berdasarkan batas maksimum cemaran logam berat pada pangan yang telah ditetapkan oleh Badan Standar Nasional Indonesia tahun 2009 pada penelitian ini maka perhitungan PTWI untuk batas aman konsumsi ikan tongkol di Pasar Dupa Pekanbaru oleh konsumen perminggu adalah $\mathrm{Pb}$ sebanyak 3,89 Kg/minggu dan $\mathrm{Cu}$ sebanyak 2456,76 Kg/minggu.

Kandungan logam $\mathrm{Pb}$ berdasarkan asal ikan tongkol yang dijual di Pasar Dupa Pekanbaru disajikan pada Tabel 4. Tabel 4 di bawah terlihat bahwa orang dewasa dengan berat badan $70 \mathrm{Kg}$ memiliki batas aman konsumsi ikan tongkol berdasarkan konsentrasi logam $\mathrm{Pb}$ yang berasal dari Tanjung Balai Asahan adalah 6,99 Kg/minggu, Padang 6,68 Kg/minggu, Sibolga 1,76 Kg/minggu, dan Air Bangis sebesar 6,04 $\mathrm{Kg} /$ minggu.

Tabel 4. Batas Aman Konsumsi Ikan Tongkol yang dijual di Pasar Dupa Berdasarkan Konsentrasi Logam $\mathrm{Pb}$

\begin{tabular}{cccc}
\hline Daerah Asal & $\begin{array}{c}\text { Kandungan Logam } \\
\text { Berat Basah }(\mu \mathrm{g} / \mathrm{g})\end{array}$ & $\begin{array}{c}\text { Nilai PTWI Masing- } \\
\text { masing Logam }(\mu \mathrm{g} / \mathrm{Kg})\end{array}$ & $\begin{array}{c}\text { Batas Aman Konsumsi } \\
\text { Ikan Tongkol }(\mathrm{Kg} / \mathrm{minggu})\end{array}$ \\
\hline Tj. Balai Asahan & 0,25 & 1.750 & 6,99 \\
Padang & 0,26 & 1.750 & 6,68 \\
Sibolga & 0,99 & 1.750 & 1,76 \\
Air Bangis & 0,29 & 1.750 & 6,04 \\
\hline
\end{tabular}

Untuk kandungan logam $\mathrm{Cu}$ berdasarkan asal ikan tongkol yang dijual di Pasar Dupa Pekanbaru disajikan pada Tabel 5 .

Tabel 5. Batas Aman Konsumsi Ikan Tongkol yang dijual di Pasar Dupa Berdasarkan Konsentrasi Logam $\mathrm{Cu}$

\begin{tabular}{cccc}
\hline Daerah Asal & $\begin{array}{c}\text { Kandungan Logam } \\
\text { Berat Basah }(\mu \mathrm{g} / \mathrm{g})\end{array}$ & $\begin{array}{c}\text { Nilai PTWI Masing- } \\
\text { masing Logam }(\mu \mathrm{g} / \mathrm{Kg})\end{array}$ & $\begin{array}{c}\text { Batas Aman } \\
\text { Konsumsi Ikan } \\
\text { Tongkol } \\
(\mathrm{Kg} / \mathrm{minggu})\end{array}$ \\
\hline Tj. Balai Asahan & 0,06 & 245.000 & 4386,44 \\
Padang & 0,06 & 245.000 & 4425,62 \\
Sibolga & 0,23 & 245.000 & 1056,79 \\
Air Bangis & 0,06 & 245.000 & 4386,44 \\
\hline
\end{tabular}


Pada Tabel 5 terlihat bahwa orang dewasa dengan berat badan $70 \mathrm{Kg}$ memiliki batas aman konsumsi ikan tongkol berdasarkan konsentrasi logam $\mathrm{Cu}$ yang berasal dari Tanjung Balai Asahan adalah 4386,44 Kg/minggu, Padang 4425,62 Kg/minggu, Sibolga 1056,79 Kg/minggu, dan Air Bangis sebesar $4386,44 \mathrm{Kg} /$ minggu.

Ikan tongkol merupakan salah satu hasil laut yang memiliki daging yang gurih dan nikmat. Selain itu, ikan tongkol mempunyai kandungan gizi yang bermanfaat bagi kesehatan tubuh. Di dalam ikan tongkol terdapat kandungan protein, vitamin $\mathrm{A}$, vitamin $\mathrm{E}$, dan kandungan mineral yang terdiri dari kalsium, fosfor serta magnesium. Ikan tongkol juga memiliki kandungan omega 3 yang bermanfaat untuk proses pencernaan dan perkembangan sel-sel di dalam otak.

\section{KESIMPULAN}

Kandungan logam berat $\mathrm{Pb}$ dan $\mathrm{Cu}$ dari hasil penelitian ini secara menyeluruh yang paling tertinggi terdapat pada ikan tongkol yang berasal dari Sibolga. Kandungan logam berat pada ikan tongkol Pasar Dupa Pekanbaru $\mathrm{Pb}$ sebesar $1 \mu \mathrm{g} / \mathrm{g}-3,98 \mu \mathrm{g} / \mathrm{g}$ dan Cu sebesar 0,22 $\mu \mathrm{g} / \mathrm{g}-0,93 \mu \mathrm{g} / \mathrm{g}$.

Status pencemaran logam berat $\mathrm{Pb}$ dan $\mathrm{Cu}$ pada ikan tongkol yang dijual di Pasar Dupa Pekanbaru masih aman dan layak untuk dikonsumsi. Batas aman konsumsi ikan tongkol Pasar Dupa Pekanbaru logam $\mathrm{Pb}$ sebesar 3,89 kg/minggu dan Cu sebesar 2456,76 kg/minggu.

\section{UCAPAN TERIMAKASIH}

Penulis menyampaikan terimakasih kepada Ibu Sepni yang telah membantu di Laboratorium Kimia Laut Universitas Riau.

\section{DAFTAR PUSTAKA}

Amin,B, 2013, Moluska Sebagai Biomonitor Pencemaran Logam Berat di Perairan Pantai Tropis, UR Press Pekanbaru.

Emirsida.,I. 2014, Kandungan Logam Berat Pada Air, Sedimen dan Tiram (Crassostrea cuculata Born) di Muara Sungai Loskala Kota Lhokseumawe Provinsi Aceh, Pekanbaru.

Hananingtyas,I. 2011. Studi Kandungan Logam Berat Timbal (Pb), Kadmium (Cd), Mercuri (Hg) pada Ikan Tongkol (Euthynnus, sp) di Pasar Ikan Rejomulyo Kota Semarang

Hidayah. 2013. Kandungan Logam Berat pada Air, Sedimen, Ikan Nila (Oreochromis niloticus linn) di Keramba Danau Rawapening

Parningotan., J.E.R, 2010, Analisa Konsentrasi Logam Berat (Pb, Cd, Cu, Ni, Zn) pada Badan Air, Sedimen dan Ikan di Perairan Kota Dumai, Pekanbaru.

Scott, J.S. and Smith, P.G. 1981. Dictionary of waste and Water Treatment. London

Sudarmaji, Mukono, J,. Dan Corit, I.P (2006). Teknologi Logam Berat B3 dan Dampaknya Terhadap Kesehatan

World Health Organization. (2010). Explosure to Cadmium: A Major Public Health Concern

Yap, C,K,A. Ismail dan S.G. Tan. 2003. Background Concentrations of $\mathrm{Cd}, \mathrm{Cu}, \mathrm{Pb}, \mathrm{Zn}$ in the GreenLipped Mussel Ppema viridis (Linnaeus) From Peninsular Malaysia. Marine Pollution Bulletin 46: 1035-1048 